\title{
STUDI DESKRIPTIF ANALISIS TERHADAP BIMBINGAN GURU DALAM MENINGKATKAN PENGUASAAN KONSEP IPA DAN HASIL BELAJAR SISWA KELAS V SD PADA PEMBELAJARAN IPA BERBANTUAN PENDEKATAN KETERAMPILAN PROSES
}

\author{
Sri Handayani \\ Budiharto \\ Triyoto \\ Sumarno \\ UPBJJ-UT Semarang \\ e-mail: shandayani@ecampus.ut.ac.id
}

\begin{abstract}
Science Learning on the V kelas of SD Magersari Rembang Magelang is still centered on teachers using lecture methods, teachers less involving students to experiment, teachers less understanding the meaning of process skill approach and low student understanding seen in learning outcomes from 33 students only 9 students or $27 \%$ complete of 24 students or $73 \%$ of students who have not finished yet. To overcome this, improvements are made with the guidance of the teacher in applying the Process Skills Approach to improve Student Learning Results on IPA. The purpose of this study is to describe: (1) Teacher planning in learning with process skill approach to improve students 'learning outcomes on light material and their properties. (2) Learning outcomes through process skills approach to improve students' learning outcomes of light materials and their properties. (3) Student learning outcomes in the process skills approach, in light materials and their properties. The subject of this study was the students of $V$ class which amounted to 33 people. Implementation of PTK used includes four stages, namely: 1) planning, 2) implementation, 3) observation, and 4) reflection. Data collection technique used: test, observation sheet and field note. The completeness of student learning outcomes in cycle I was $41 \%$, increased in cycle 2 to $64 \%$ and increased again in cycle III to $82 \%$ above the expected target of $80 \%$. The result of this research shows that application of process skill approach can improve the result of science learning. Suggestions for teachers in implementing learning should use innovative learning models, so that student learning outcomes will improve according to the situation and local environmental conditions.
\end{abstract}

Keywords: concept mastery, process skills approach, teacher guidance.

\begin{abstract}
ABSTRAK
Pembelajaran IPA pada siwa kelas V SDN Magersari Rembang masih berpusat pada guru menggunakan metode ceramah, guru kurang melibatkan siswa melakukan percobaan, guru kurang memahami arti pendekatan keterampilan proses dan rendahnya pemahaman siswa terlihat pada hasil belajar dari 33 siswa hanya 9 siswa atau27\% siswa yang tuntas dari 24 siswa atau $73 \%$ siswa yang belum tuntas. Untuk mengatasinya, dilakukan perbaikan dengan bimbingan guru dalam menerapkan Pendekatan Keterampilan Proses untuk meningkatkan Hasil Belajar Siswa pada IPA.Penelitian ini bertujuan untuk mendeskripsikan: (1) Perencanaan guru dalam pembelajaran dengan pendekatan keterampilan proses untuk
\end{abstract}


meningkatkan hasil belajar siswa pada materi cahaya dan sifat-sifatnya. (2) Pelaksaanaan pembelajaran melalui pendekatan keterampilan proses untuk meningkatkan hasil belajar siswa materi cahaya dan sifat-sifatnya. (3) Hasil belajar siswa dalam pendekatan keterampilan proses, pada materi cahaya dan sifat-sifatnya. Subyek penelitian ini adalah siswa kelas $V$ yang berjumlah 33 orang. Pelaksanaan PTK yang digunakan meliputi empat tahapan, yaitu: 1) perencanaan, 2) pelaksanaan, 3) observasi, dan 4) refleksi. Teknik pengumpulan data yang digunakan: tes, lembar observasidan catatan lapangan.

Ketuntasan hasil belajar siswa pada siklus I sebesar $41 \%$, meningkat pada siklus 2 menjadi $64 \%$ dan meningkat kembali di siklusIII menjadi $82 \%$ diatas target yang diharapkan yaitu $80 \%$. Hasil penelitian inimenunjukkan bahwa penerapan pendekatan keterampilan proses dapat meningkatkan hasil belajar IPA. Saran untuk gurudalam melaksanakan pembelajaran sebaiknya menggunakan model pembelajaran yang inovatif, sehingga hasil belajar siswa menjadi meningkat sesuai situasi dankondisi lingkungan setempat.

Kata kunci: bimbingan guru, pendekatan keterampilan proses, penguasaan konsep.

Pendidikan sangat penting dan berpengaruh bagi kehidupan manusia karenadengan pendidikan manusia dapat berdaya guna dan mandiri.Namun masalah pendidikan menjadi hal yang paling utama bahkan menjadi perhatian dan penanganan khususnya pemerintah. Pemerintah berupaya meningkatkan mutu pendidikan dan mengadakan inovasi-inovasi baru untuk mengatasi berbagai masalah pendidikan agar pendidikan di Indonesia dapat berkembang dan mampumenghadapi persaingan global. Berdasarkan Peraturan Pemerintah tentang Standar Nasional Pendidikanpasal 19 ayat (I) menyebutkan bahwa: proses pembelajaran pada satuan pendidikan diselenggarakan secara interaktif, inspiratif, menyenangkan,menantang, memotivasi siswa untuk berperan aktif, memberikan ruang gerak yang cukup bagi prakarsa kreativitas dan kemandirian sesuai dengan bakat, minat dan perkembangan fisik serta psikologi siswa. IPA atau sains merupakan suatu kumpulan pengetahuan yang tersusun secara sistematis, dan dalam penggunaannya secara umum terbatas pada gejala-gejala alam. Hal ini sejalan dengan Kurikulum Tingkat Satuan Pendidikan (Depdiknas, 2006:17) bahwa: "IPA berhubungan dengan cara cari tahu tentang alam secara sistematis, sehingga bukan hanya penguasaan kumpulan pengetahuan berupa fakta, konsep atau prinsip saja tetapi juga merupakan suatu proses temuan. "Selain itu IPA juga merupakan ilmu yang bersifat empirik dan membahas pembelajaran IPA tidak hanya verbal tetapi juga faktual. Hal ini menunjukkan bahwa hakikat IPA sebagai proses diperlukan untuk menciptakan pembelajaran IPA yang empirik dan faktual. Hakikat IPA sebagai proses diwujudkan dengan melaksanakan pembelajaran keterampilan proses sebagai cara produk sains ditemukan.

Pembelajaran IPA dibutuhkan untuk mengembangkan keterampilan proses pada diri siswa sebagai dasar untuk dapat memahami konsep-konsep IPA, hal tersebut dipengaruhi oleh metode pembelajaran yang digunakan agar dapat meningkatkan hasil belajar IPA. Oleh karena itu, keterampilan proses dalam pembelajaran sangat diperlukan sehingga daya ingat siswa menguasai konsep yang dipelajari akan menjadi lebih baik. Maka kreatifitas seorang guru dalam mengajarkan IPA juga dituntut agar memudahkan dan menyenangkan siswa dalam pembelajaran.

Dengan menggunakan keterampilan proses dalam pembelajaran IPA berarti memandang siswa sebagai subyek belajar yang diharapkan dapat mengembangkan kognitif, afektif, dan psikomotorik dengan baik. Hal ini sesuai dengan pernyataan Hedriani (1995:5) bahwa: Keterampilan 
proses adalah keterampilan intelektual sosial maupun sosok yang diperlukan untuk dapat mengembangkan lebih lanjut pengetahuan atau konsep yang dimiliki. Dengan dimilikinya keterampilan ini siswa berpeluang untuk dapat memperoleh konsep-konsep baru atau informasiinformasi baru.

Hal ini sejalan dengan pendapat Pudjiadi (1996:5) bahwa: "siswa dapat berminat dalam mempelajari IPA apabila diberi kesempatan melakukan aktivitas pembelajaran melalui pengamatan secara nyata atau dengan melakukan percobaan IPA yang telah disiapkan dalam pengajaran secara verbal". Siswa diharapkan menguasai tiga keterampilan proses melalui mempredeksikan, mengamati dan menjelaskan atau Predict, Observe and Explain (P.O.E.). P.O.E. membelajarkan siswa dengan membuat prediksi suatu materi berdasarkan konsepsi mereka sendiri, kemudian mengobservasi pengetahuan materi tersebut secara nyata, dan yang terakhir menjelaskan hasil pengamatan mereka serta menjelaskan ketidaksesuaian prediksi mereka denngan keadaan yang sebenarnya.

Penerapan pendekatan keterampilan proses sesuai dengan karakteristik pembelajaran IPA dengan materi cahaya dan sifat-sifatnya, dengan cara siswa melakukian diskusi, siswa dapat bertukar pikiran mengenai materi yang dipelajari dan memiliki kesempatan yang sama dalam proses belajar mengajar. Lebih jelasnya bahwa pembelajaran IPA akan lebih baik apabila dilakukan dengan memprediksi, mengamati dan menjelaskan hasil diskusi sehingga semua kelompok dituntut untuk memahami materi yang dipelajari.

Berdasarkan latar betakang masalah tersebut di atas, tujuan yang akan dicapai pembelajaran dengan pendekatan keterampilan proses dapat meningkatkan hasil belajar siswa dan memahami konsep-konsep IPA pada materi cahaya dan sifat-sifatnya dengan bantuan bimbingan guru. Dengan mempertimbangkan hal tersebut maka peneliti bermaksud mengadakan PenelitianTindakan Kelas pada kelas VSDN Magersari Rembang tahun pelajaran 2016-2017 dengan judul "Studi Deskriptif Analisis Terhadap Bimbingan Guru Dalam Meningakatkan Penguasaan Konsep IPA dan Hasil Belajar Siswa kelas V pada Pembelajaran IPA Berbantuan Pendekatan Keterampilan Proses.

\section{KAJIAN PUSTAKA.}

Salah satu pendekatan keterampilan proses yang diungkapkan oleh Purba dan Wartono (1991:10) bahwa : "Pendekatan keterampilan prosesadalah cara memandang anak didik sebagai manusia seutuhnya. Cara memandang ini diterjemahkan dalam kegiatan mengajar yang sekaligus memperhatikan pengembangan dan pengetahuan , nilai dan siakp serta keterampilan".

Berdasarkan ungkapan diatas, maka dapat dikatakan bahwa pendekatan keterampilan proses sangat diperlukan dalam pembelajaran IPA karena dapat memberikan kesempatan kepada siswa untuk menggali potensi yang dimilikinya dengan cara melibatkan siswa secara langsung dalam proses belajar mengajar. Keterampilan proses mengamati atau observasi merupakan salah satu keterampilan proses dasar. Keterampilan mengamati menggunakan kelima indera yaitu penglihatan, peraba, pembau, pengecap dan pendengar. Apabila siswa mendapatkan kemampuan melakukan pengamatan yang menggunakan beberapa indera , maka kepekaan dan kesadaran mereka terhadap segala hal disekitarnya akan berkembang. Keterampilan menjelaskan disini berarti siswa mengajukan hipotesisdan mampu menjelaskan perbedaan antara prediksi yang dibuatnya dengan hasil observasinya. (Indrawati dan Setiawan, 2009:45).

Hasil belajar adalah kemampuan yang dimiliki siswa setelah ia menerima pengalaman belajarnya. (Nana, 2009:22). Belajar itu sendiri merupakan suatu proses dari seseorang yang berusaha untuk memperoleh suatu bentuk perilaku yang relatif menetap. Setelah melalui proses 
belajar maka siswa dapat mencapai hasil belajar yaitu kemampuan yang dimiliki siswa setelah menjalani proses belajar. Berdasarkan teori Taksonomi Bloom hasil belajar siswa dapat diklasifikasikan kedalam tiga ranah yaitu kognitif, afektif dan psikomotor. (Purwanto, 2007:43). Tiga ranah tersebut adalah: (1) Ranah kognitif meliputi mengingat, memahami, mengaplikasi atau menertapkan, menganalisis, mengevaluasi dan mengkreasi; (2) Ranah Afektif meliputi kesadaran, partisipasi, penghayatan nilai, pengorganisasian nilai dan karakteristik diri; (3) Ranah psikomotor yaitu kemampuan motorik dengan gerak reflek, gerakan dasar, gerakan terlatih dan jasmani.

Menurut Kurikulum 2012 yang berbasis pada tujuan pembelajaran IPA untuk sekolah dasar pada prinsipnya membekali siswa untuk memiliki kemampuan berbagai cara untuk mengetahui dan cara mengerjakan yang dapat membantu siswa dalam memahami alam sekitar. Sedangkan tujuan pembelajaran di SD adalah: (1) menanamkan rasa ingin tahu dan sikap positif terhadap IPA, tehnologi dan masyarakat; (2) mengembangkan keterampilan proses untuk menyelidiki alam sekitar, memecahkan masalah dan membuat keputusan; (3) mengembangkan pengetahuan dan pemahaman konsep IPA yang akan bermanfaat dalam kehidupan sehari-hari; (4) ikut serta memelihara, menjaga dan melestarikan lingkungan alam (5) menghargai alam sekitar dan segala keteratrurannya sebagai salah satu ciptaan Tuhan.

\section{METODE PENELITIAN}

Penelitian ini memiliki tujuan untuk memecahkan permasalahan pokok yaitu meningkatkan hasil belajar siswa dalam pembelajaran IPA dengan memperbaiki efisiensi dan efektivitas pembelajaran melalui pendekatan keterampilan proses. Melalui penelitian ini diharapkan ada solusi terbaik untuk mengatasi permasalahan yang ada didalam proses pembelajaran, maka penelitian ini menggunakan Metode Penelitian Tindakan Kelas (PTK). Pelaksanaan Penelitian Tindakan Kelas ini meliputi empat langkah yaitu: (1) perencanaan tindakan; (2) pelaksanaan tindakan; (3) observasi dan (4) refleksi (Depdiknas, 2004:2).

Subyek yang akan diteliti adalah siswa Kelas V SD Negeri Magersari, Rembang, Tahun Ajaran 2016/2017. Instrumen penelitian adalah alat yang digunakan untuk mengumpulkan data . Kegiatan pengumpulan data dilakukan dengan lembar observasi siswa dan lembar observasi guru, catatan lapangan dan tes hasil belajar.

\section{HASIL DAN PEMBAHASAN}

Penelitian ini terdiri dari 3 siklus dimana setiap siklus dilaksanakan sesuai dengan perubahan yang ingin dicapai. Adapun faktor yang diteliti yaitu: Rencana Pelaksanaan Pembelajaran dengan pendekatan keterampilan proses, pelaksanaan pembelajaran dengan keterampilan proses dan hasil belajar siswa setelah mengikuti pembelajaran dengan menggunakan pendekatan keterampilan proses. Tahapan PTK ini dengan prosedur adalah: (1) Perencanaan (planning); (2) Pelaksanaan (action); (3) Pengamatan (observation); (4) Refleksi (reflection)

Penelitian ini terdiri dari 3 siklus yaitu:

\section{Siklus I:}

1. Perencanaan.

Peneliti dan guru menyusun RPP dengan menggunakan pendekatan keterampilan proses dengan materi cahaya dan sifat-sifatnya, dengan ciri : (a) Guru membagi siswa dalam kelompok, (b) Setiap kelompok memprediksi suatu kejadian, (c) Melakukan pengamatan langsung (d). Berpikir bersama dalam kelompok untuk menyatukan pendapat dari hasil 
pengamatannya. (e) Guru memberikan kesempatan siswa untuk menjelaskan hasil pengamatannya secara kelompok. (f) Setiap kelompok melaporkan hasil diskusinya.

2. Pelaksanaan Tindakan ( 10 September 2016 )

Dalam pelaksanaan pembelajaran dengan langkah-langkah:

a. Kegiatan Awal: Memberi salam, mencek kehadiran siswa dilanjutkan dengan apersepsi dan membagi siswa dalam kelompok.

b. Kegiatan Inti: (1) Guru memberikan pertanyaan untukmengetahui pemahaman siswa tentang cahaya dan sifat-sifatnya; (2) Guru membagi LKS secara kelompok; (3) Guru membagi alat peraga (cermin datar, cembung, cekung; (4) Siswa mencatat hasil pengamatan tentang cahaya merambat lurus, menembus benda bening , cahaya dapat dipantulkan.

c. Kegiatan Akhir: (1) Guru tidak menyimpulkan pelajaran bersama siswa; (2) Setelah melakukan prediksi, pengamatan dan penjelasan tentang materi, guru kemudian membagikan soal sebagai evaluasi individu. Diakhir siklus akan diketahui hasil belajar siswa setelah mengikuti tes.

3. Observasi terhadap RPP, Siswa dan Guru dalam pembelajaran.

4. Refleksi , Terdapat kelemahan baik dari segi siswa, guru maupun RPP, hal ini akan

Siklus II: diperbaiki pada siklus berikutnya.

1. Perencanaan: (1) Melakukan perbaikan dari RPP siklus I kedalam RPP siklus II, dengan materi yang sama; (2) Jumlah siswa dalam kelompok hanya 1-4 orang.

2. Pelaksanaan Tindakan ( 14 September 2016 ).

a. Kegiatan Awal: Memberi salam, mencek kehadiran siswa dilanjutkan dengan apersepsi dan membagi siswa dalam kelompok. Menyiapkan alat-alat yang akan digunakan , menyampaikan tujuan pembelajaran.

b. Kegiatan Inti: (1) Guru memberikan pertanyaan untuk mengetahui pemahaman siswa tentang sifat cahaya dapat dibiaskan, dengan pertanyaan sebagai berikut: Apakah dasar kolam yang airnya jernih itu tampak dangkal? (2) Guru membagi LKS dan meminta siswa berkelompok untuk mengerjakan; (3) Melakukan percobaan, pembiasan melalui dua medium yang berbeda, langkahnya: mengisi mangkuk dengan air dan mencelupkan sebagian pensil ke dalam air dan mengamati apa yang terjadi. Siswa maju melaporkan hasil percobaannya, yaitu: (1) Pensil tampak lurus; (2) Cahaya mengalami pembiasan jika melalui medium yang berbeda; (3) Dengan bimbingan guru siswa menjelaskan bahaya merambat dari zat yang kurang rapat ke zat yang lebih rapat.

c. Kegiatan akhir: Guru bersama siswa menyimpulkan dan membagikan soal untuk mengetahui hasil belajar siswa. Hasil belajar.

3. Refleksi: Berdasarkan hasil observasi terhadap guru dan siswa serta catatan lapangan peneliti, masih ditemukan kelemahan pada siklus II baik siswa (diskusi masih ada beberapa anak yang belum terfokus, belum semua anak berani menjelaskan didepan kelasmaupun guru (perhatian Siklus III: guru belum merata, dan kurang memberikan pujian pada siswa yang menjawab benar.

1. Perencanaan

RPP yang dibuat peneliti dan guru masih sama dengan siklus sebelumnya, namun pokok bahasan yang berbeda yaitu tentang penerapan sifat-sifat cahaya dengan membuat karya, sehingga dalam pembelajaran perlu diadakan penambahan yaitu ketika guru kelas menunjuk 
secara acak nomor siswa untuk melaporkan hasil pengamatannya dan mendemonstrasikan hasil kegiatannya serta menjelaskan masalah yang ditemukan dari hasil pengamatannya dalam diskusi kelompok.

2. Pelaksanan Tindakan.

Tindakan perbaikan dilakukan tanggal 15 Oktober 2016, melalui:

a. Kegiatan awal: Memberi salam, mencek kehadiran siswa dilanjutkan dengan apersepsi dan membagi siswa dalam kelompok. Menyiapkan alat-alat yang digunakan, menyampaikan tujuan pembelajaran. Memberi pertanyaan tentang periskop. Siswa dibagi dalam kelompok (1-4 orang) dan menyiapkan alat-alat yang diperlukan,

b. Kegiatan inti:yang dilakukan guru: (1) Memberikan pertanyaan untuk mengetahui pemahaman siswa tentang periskop dan cakram warna; (2) Siswa memprediksi pertanyaan guru; (3) Menulis prediksi siswa dipapan tulis; (4) Membagi kelompok yang membuat periskop dan cakram warna; (5) Membagi LKS berisi cara membuat periskop dan cakram warna; (6) Siswa mengerjakan LKS secara kelompok; (7)Siswa menguji hasil karya.

c. Kegiatan akhir: (1) Guru memberi kesempatan kepada siswa untuk menanyakan hal-hal yang belum jelas: (2) Guru bersama siswa menyimpulkan hasil pembelajaran siklus III

d. Hasil belajar: Setelah diadakan tes, dapat diketahui hasil belajar siswa.

Penggunaan pendekatan keterampilan proses dalam pembelajaran IPA di Kelas V SD Negeri Magersari Rembang, telah membawa perubahan yang cukup berarti dibanding pembelajaran sebelumnya. Hal ini telah terbukti setelah dilakukan perbaikan pembelajaran dalam 3 siklus. Dari siklus I sampai siklus II masih dijumpai berbagai kelemahan baik dari fihak siswa, guru maupun RPP. Dari segi RPP misalnya dalam penentuan Kelompok kecil pada Siklus I masih 8 orang siswa dalam 1 kelompok, sehingga pada siklus II di perbaiki menjadi hanya 4 orang siswa dalam 1 kelompok, hal ini lebih efektif dan berpengaruh pada hasil belajar. Dari segi siswa, dijumpai siswa yg kurang aktif atau kurang konsentrasi dalam pembelajaran, maka dalam siklus II hal ini dapat diatasi dan pada siklus III sudah sesuai dengan harapan. Secara bertahap kelemahan tersebut dapat diatasi. Kemajuan penguasaan konsep IPA dan hasil belajar tentang cahaya dan sifat-sifatnya nampak dari hasil penelitian dari siklus I sampai siklus III seperti pada Tabel 1.

Tabel 1. Rentang Nilai Hasil Belajar Siswa dalam Siklus I

\begin{tabular}{cccccc}
\hline Rentang Nilai & Frekuensi & Persentase & Rentang Nilai & Frekuensi & Persentase \\
\hline $88-100$ & 1 & $3 \%$ & $28-37$ & $13 \%$ \\
$78-87$ & 6 & $19 \%$ & $0-27$ & $9 \%$ \\
$68-77$ & 6 & $19 \%$ & Jumlah & $100 \%$ \\
$58-67$ & 5 & $16 \%$ & Tuntas & $41 \%$ \\
$48-57$ & 4 & $13 \%$ & Tidak Tuntas & $59 \%$ \\
$38-47$ & 3 & $9 \%$ & & \\
\hline
\end{tabular}

Berdasarkan sebaran rentang nilai hasilbelajar siswa pada siklus I, bila dituangkan dalam bentuk diagram maka akantampak pencapaian hasil belajar siswa seperti pada Gambar 1. 


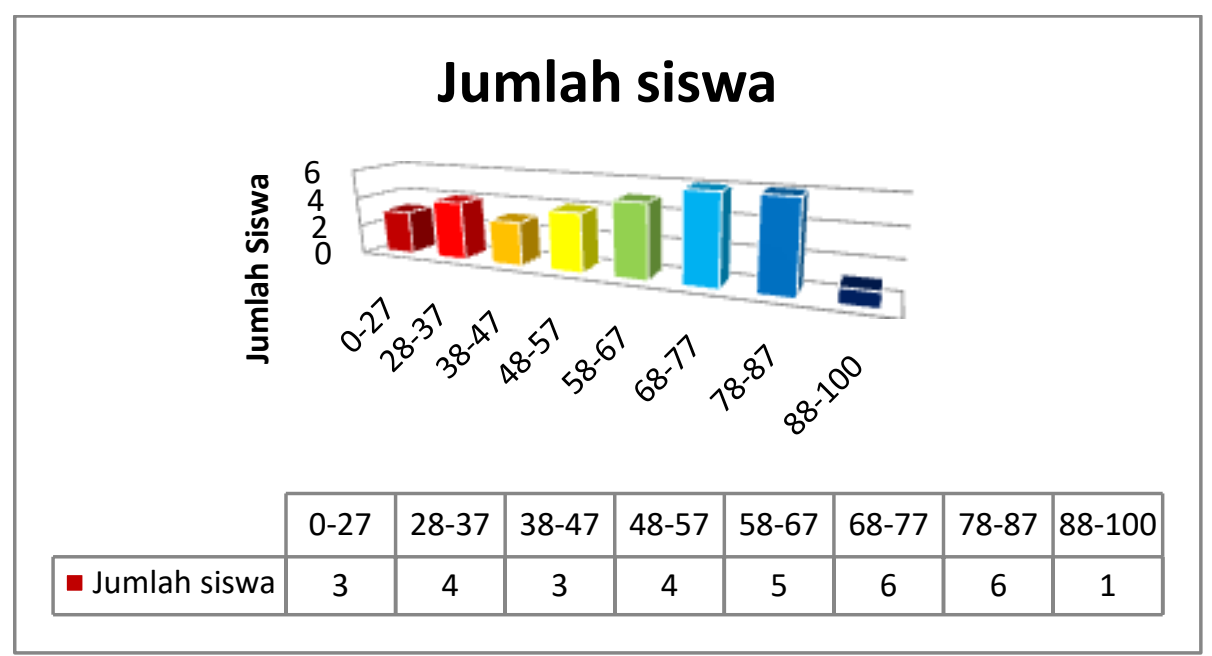

Gambar 1. Diagram hasil belajar Siklus I

Gambar 2 mendiskripsikan hasil belajar dari 32 siswa pada siklus I adalah siswa yang mendapat nilai pada rentang nilai 0-27 terdapat 3 siswa, rentang nilai 28-37 terdapat 5 siswa, pada rentang nilai 38-47 terdapat 2 siswa yang memperoleh nilai tersebut, kemudian pada rentang nilai 4857 terdapat 4 siswa yang memperoleh nilai tersebut, pada rentang nilai 58-67 terdapat 5 siswa, pada rentang nilai 68-77 terdapat 6 siswa yang memperoleh nilai tersebut, pada rentang nilai 78-87 terdapat 6 siswa, dan pada rentang nilai 88-100 terdapat 1 siswa yang memperoleh nilai tersebut. Nilai hasil belajar siswa pada penelitan Siklus II dikelompokkan dalam rentang nilai seperti pada Tabel 2.

Tabel 2. Rentang Nilai Hasil Belajar Siswa dalam Siklus II

\begin{tabular}{|c|c|c|c|c|c|}
\hline Rentang Nilai & Frekuensi & Persentase & Rentang Nilai & Frekuensi & Persentase \\
\hline $88-100$ & 1 & $3 \%$ & $28-37$ & & $0 \%$ \\
\hline $78-87$ & 8 & $24 \%$ & $0-27$ & & $0 \%$ \\
\hline $68-77$ & 12 & $36 \%$ & Jumlah & & $100 \%$ \\
\hline $58-67$ & 3 & $9 \%$ & Tuntas & & $64 \%$ \\
\hline $48-57$ & 7 & $21 \%$ & Tidak Tuntas & & $36 \%$ \\
\hline $38-47$ & 2 & $6 \%$ & & & \\
\hline
\end{tabular}

Berdasarkan sebaran rentang nilai hasil belajar siswa pada siklus I, bila dituangkan dalam bentuk diagram maka akan tampak pencapaian hasil belajarsiswa seperti pada Gambar 2. 


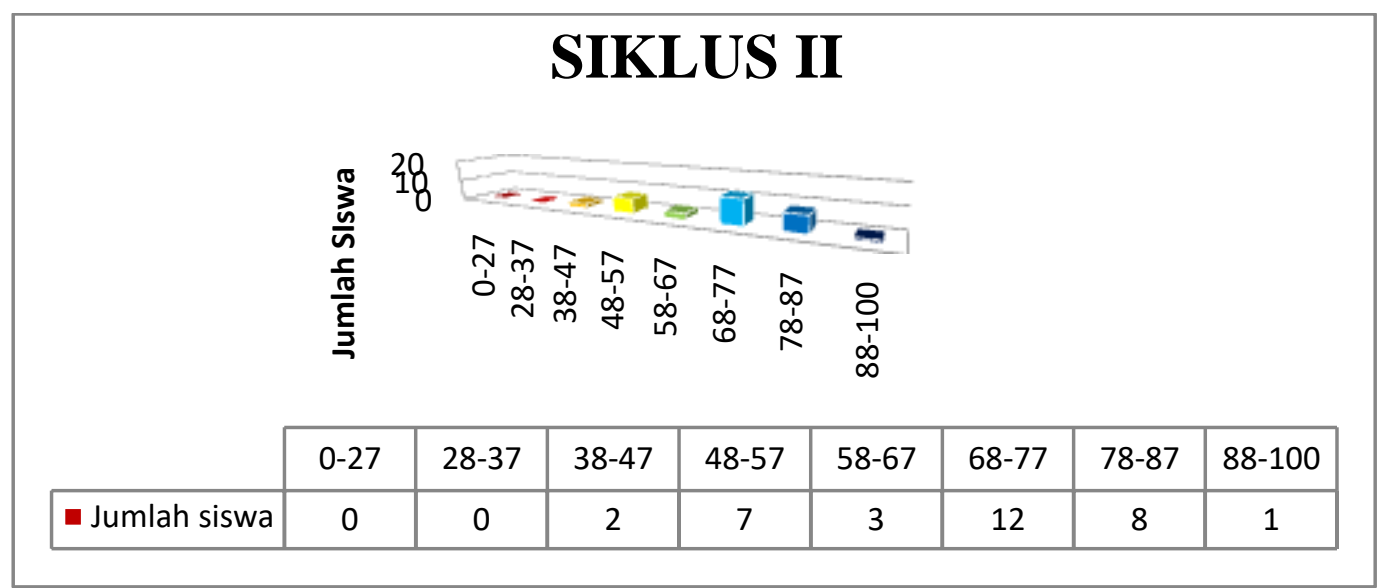

Gambar2. Diagram Hasil Belajar Siklus II Gambar 3.

Sehingga perbandingan hasil belajar Pra siklus, siklus 1dan siklus II adalah seperti pada

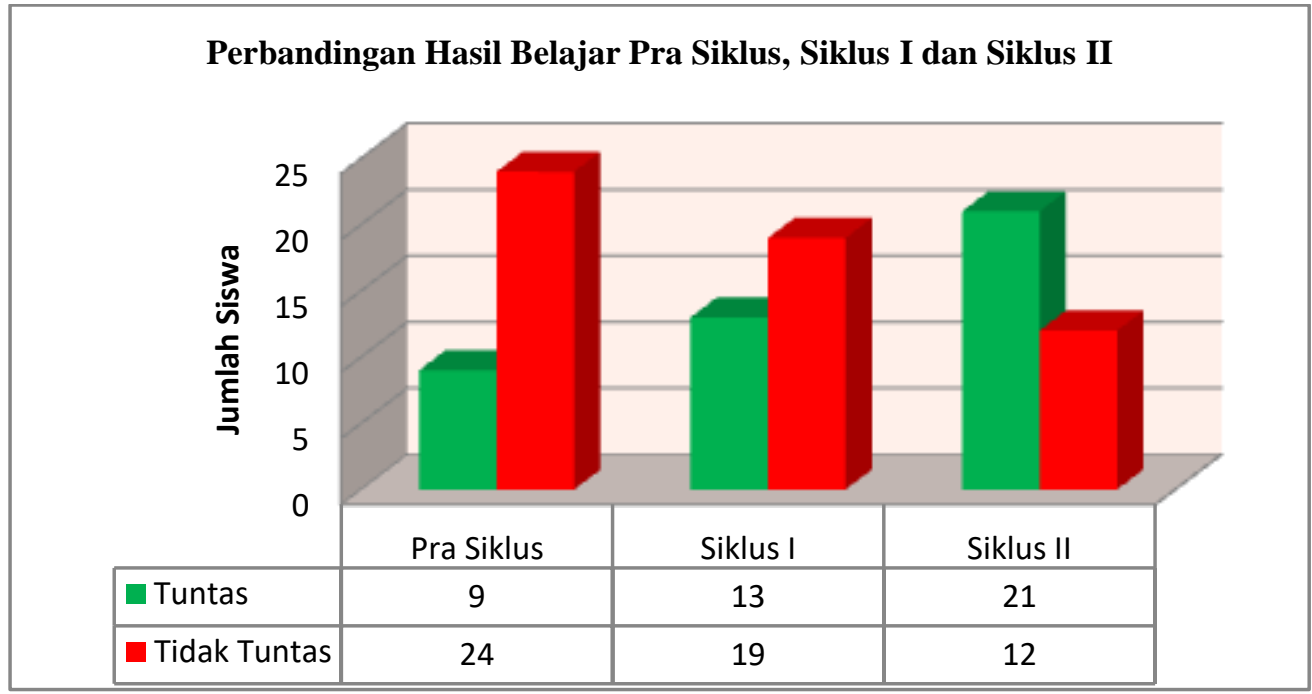

Gambar 3.Perbandingan hasil belajar Pra Siklus, Siklus I dan Siklus II

Pada Gambar 3 terlihat peningkatan hasil belajar siswa mulai dari PraSiklus, Siklus I dan Siklus II dimana sebelum diadakannya tindakan hanya 9 siswa yang tuntas mencapai KKM 68, setelah diadakan penelitian Siklus I ketuntasan belajar meningkat menjadi 13 siswa yang memperoleh nilai KKM 68, hingga di siklus II terjadi peningkatan kembali menjadi 21 siswa yang mencapainilai KKM 68. Karena jumlah siswa yang tuntas belajar belum mencapai indikator kinerja yang sudah ditargetkan oleh peneliti yaitu di atas $80 \%$. Berdasarkan hipotesis,peneliti melanjutkan ke siklus berikutnya agar peneliti benar-benar yakin penerapan Pendekatan Keterampilan Proses dapat meningkatkan hasil belajar siswa dalam pembelajaran IPA materi cahaya dan sifat-sifatnya.

Guru melakukan evaluasi untuk mengetahui hasil belajar siswa, diperoleh data bahwa terjadi peningkatan pada hasil belajar siswa. Data hasil belajar siswa dikelompokkan menurut rentang 
tertentu yang tersaji dalam tabel dan diperoleh data bahwa nilai rata-rata siswa adalah 74 yang lebih besar dari siklus-siklus sebelumnya dan terjadi peningkatan pada hasil belajar siswa. Data hasil belajar siswa tersaji dalam Tabel 3 .

Tabel 3. Rentang Nilai Hasil Belajar Siswa dalam Siklus III

\begin{tabular}{cccccc}
\hline Rentang Nilai & Frekuensi & Persentase & Rentang Nilai & Frekuensi & Persentase \\
\hline $88-100$ & 2 & $6 \%$ & $28-37$ & 0 & $0 \%$ \\
$78-87$ & 9 & $27 \%$ & $0-27$ & 0 & $0 \%$ \\
$68-77$ & 16 & $48 \%$ & Jumlah & 33 & $100 \%$ \\
$58-67$ & 2 & $6 \%$ & Tuntas & 27 & $82 \%$ \\
$48-57$ & 4 & $12 \%$ & Tidak Tuntas & 6 & $18 \%$ \\
$38-47$ & 0 & $0 \%$ & & & \\
\hline
\end{tabular}

Tabel 3 mendiskripsikan hasil belajar IPA pada siklus III dari -13 siswa kelas V menunjukkan hasil sebaran sebagai berikut siswa mendapat rentang nilai 88-100 sebanyak 2 siswa dengan persentase $6 \%$ siswa yangmendapat rentang nilai $78-87$ sebanyak 9 siswa dengan persentase $27 \%$, siswa yang mendapat rentang nilai 68-77 sebanyak 16 siswa dengan persentase $28 \%$, siswa yang mendapat rentang nilai 58-67sebanyak 2 siswa dengan persentase $6 \%$, siswa yang mendapat rentang nilai 48-57 sebanyak 4 siswa dengan persentase $12 \%$, dan tidak ada siswa yang termasuk dalam rentang nilai 38-47, rentang nilai 28-37 dan 0-27. Berdasarkan sebaran rentang nilai hasil belajar siswa pada siklus I, bila dituangkan dalam bentuk diagram maka akan tampak pencapaian hasil belajar siswa seperti pada Gambar 4.

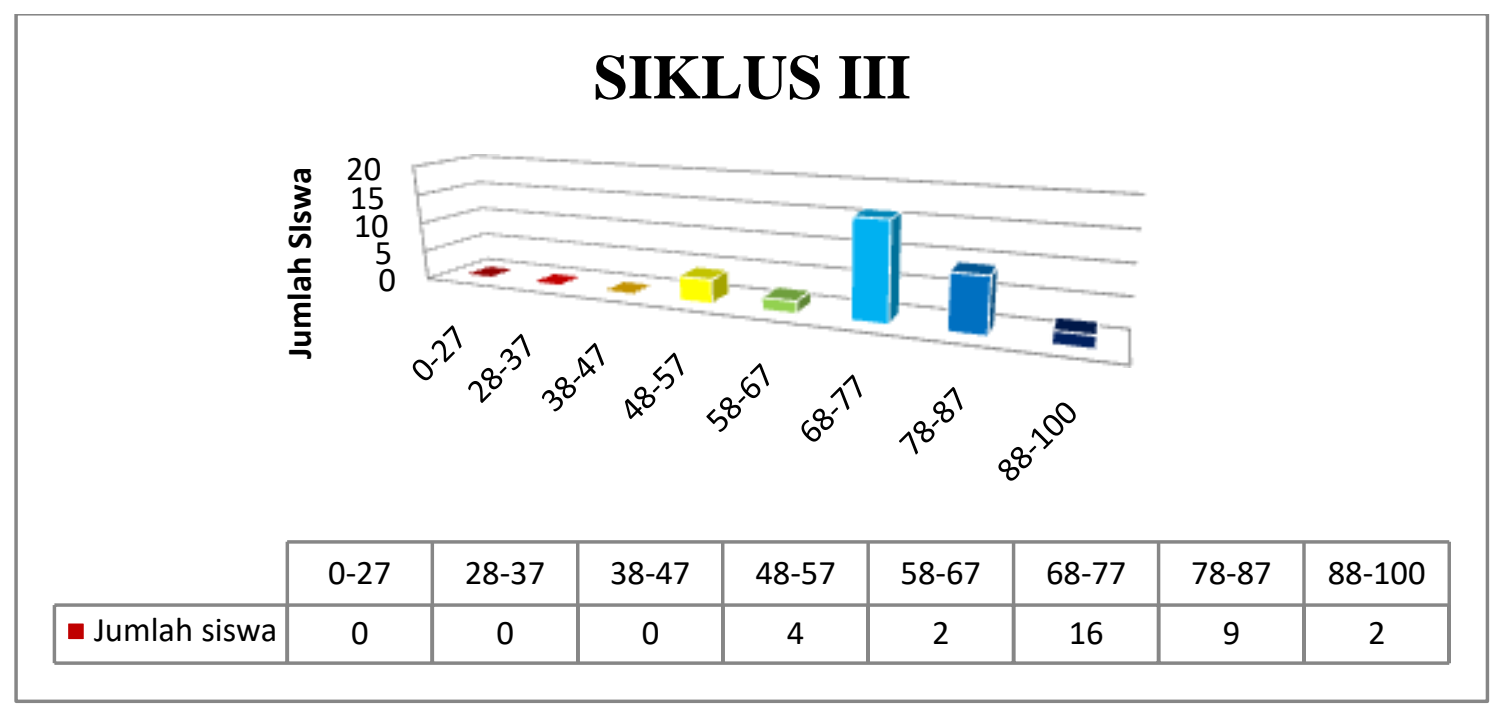

Gambar 4. Diagram hasil belajar Siklus III

Gambar 4. mendiskripsikan hasil belajar dari 33 siswa pada siklus III adalah tidak terdapat siswa yang mendapat nilai pada rentang nilai 0-27 rentangnilai 28-37, dan pada rentang nilai 38-47. Pada rentang nilai 48-57 terdapat 4 siswa yang memperoleh nilai tersebut, pada rentang nilai 58-67 terdapat 2 siswa, pada rentang nilai 68-77 terdapat 16 siswa yang memperoleh nilai tersebut, 
padarentang nllai 78-87 terdapat 9 siswa selanjutnya pada rentang nilai 88-100 terdapat 2 siswa yang memperoleh nilai tersebut. Tabel 4 disajikan distribusi ketuntasan belajar siswa:

Tabel 4.Ketuntasan Belajar Siswa Siklus III

\begin{tabular}{cccc}
\hline KKM & Frekuensi & Persentase & Keterangan \\
\hline$<68$ & 27 & $82 \%$ & Tuntas \\
$\geq 68$ & 6 & $18 \%$ & Tidak Tuntas \\
\hline Jumlah & 33 & $100 \%$ & \\
\hline
\end{tabular}

Tabel 4 mendiskripsikan ketuntasan belajar siswa siklus V dari 33 siswa kelas V menunjukkan hasil sebaran sebagai berikut, ada 12 siswa nilainya masih di bawah KKM IPA 68 atau sebesar $36 \%$ siswa belum tuntas belajar, dan 2I siswa yang nilainya lebih besar dari KKM IPA 68 atau sebesar $64 \%$ siswa tuntas belajar. Jumlah ketuntasan belajar dari 33 siswa pada siklus III jumlah ketuntasan tersebut adalah sebagai berikut siswa yang mendapatnilai di bawah KKM IPA 68 atau tidak tuntas yaitu sebanyak 6 siswa sedangkan siswa yang mendapat nilai lebih besar dari KKM IPA 68 yaitu sebanyak 27siswa. Dapat disimpulkan bahwa terjadi peningkatan hasil belajar pada siklus III jika dibandingkan dengan sebelum diadakannya tindakan, siklus I dan siklus II yang digambarkan dalarn diagram pada Gambar 6.

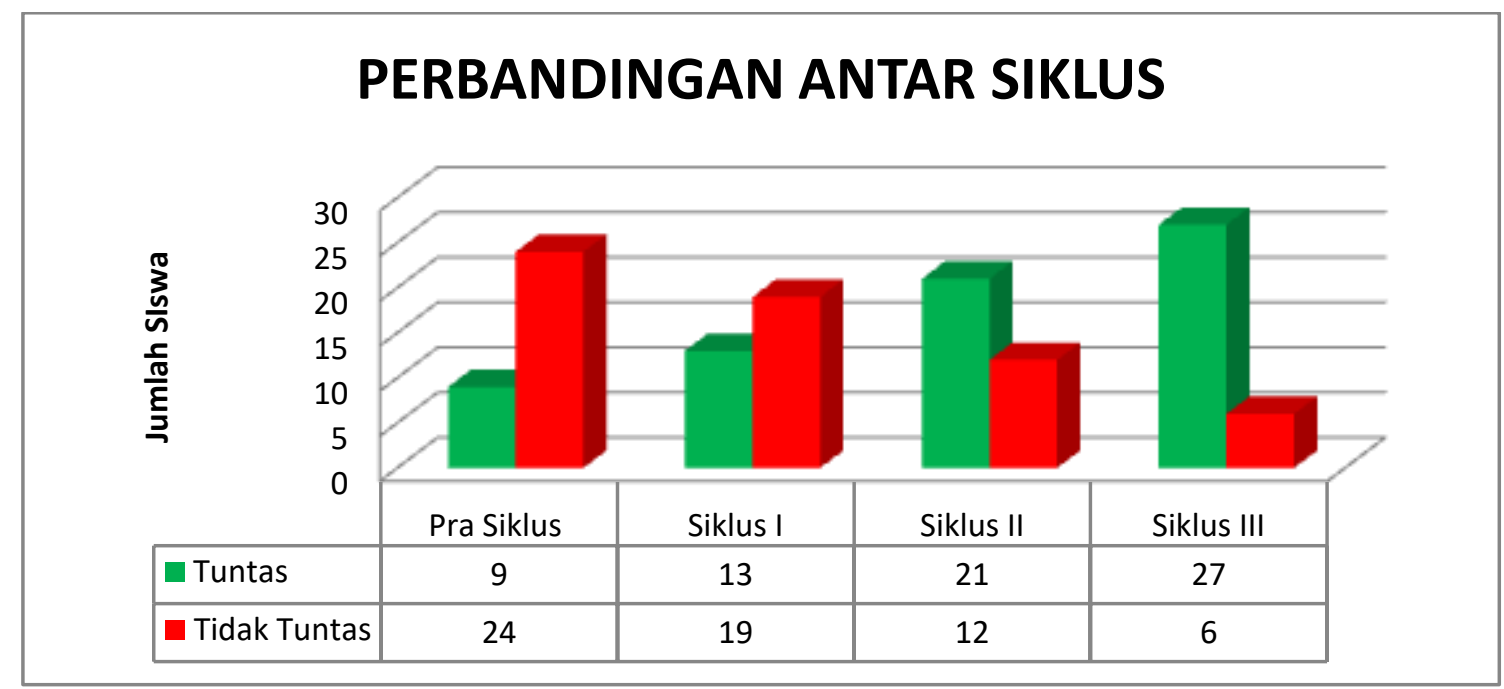

Gambar 6.Diagram perbandingan Pra Siklus, Siklus I, Siklus II dan Siklus III

Peningkatan ketuntasasan hasil belajar siswa dari sebelum tindakan (pra siklus), ke siklus I dan siklus II serta siklus III dapat diketahui berdasarkan kondisi awal atau pra siklus dari 33 siswa yang memenuhi kriteria KKM IPA 68 atau tuntas belajar hanya 9 siswa sedangkan yang tidak tuntas sebanyak 24 siswa, setelah diadakan tindakan dengan menerapkan Pendekatan Keterampilan Proses (Predict-Observe-Explain) pada siklus Irneningkat menjadi 13 siswa yang memenuhi KKM IPA 68 atau tuntas belajar sedangkan siswa yang tidak tuntas sebanyak 19 siswa, kemudian setelah diadakan tindakan pada siklus II meningkat menjadi 2I siswa yang memenuhi KKM IPA 68 atau tuntas belajar sedangkan siswa yang tidak tuntas belajar sebanyak 12 siswa dan pada siklus III 
ketuntasan siswa mengalami peningkatan kembali sebanyak 27 siswa. Hal tersebut terjadi tidak terlepas dari persiapan guru yang optimal, dan para siswa yang memiliki kemauan keras dan disiplin tinggi dalam pembelajaran dan materi IPA yang dibahas memang materi yang cukup disenangi oleh siswa. Sehingga guru dalam melakukan perbaikan pembelajaran dapat melibatkan siswa secara maksimal. Keberhasilan ini juga tidak terlepas dari kerja teman sejawat yang memantau pembelajaran dan memberikan informasi yang positif kepada guru sehingga ketika diberikan kritik dan masukan serta saran yang sifatnya membangun, dengan lapang dada dan ketulusan hati guru menerima sepenuhnya secara iklas, dan mau memperbaiki pembelajaran untuk siklus berikutnya.

Pada siklus III diperoleh nilai rata-rata74 dan dan ketuntasan belajar siswa sebesar $82 \%$. Karena jumlah siswa yang tuntas belajar sudah mencapai target peneliti yaitu diatas $80 \%$ sehingga Penelitan Tindakan Kelas berhenti sampai disini. Setelah peneliti melaksanakan tindakan siklus I, siklus II dan siklus III, hasilyang diperoleh sangat memuaskan, hal itu ditunjukan melalui hasil belajar pada siklus I sampai dengan siklus III terjadi peningkatan persentase ketuntasan belajar siswa. Terjadi peningkatan ketuntasan siswa, yang dibuktikan dari kondisi awal (pra siklus) dari 33 siswa yang memenuhi kriteria KKM IPA 68 sebanyak 9 siswa dengan persentase sebesar $27 \%$, setelah siklus I meningkat menjadi 13 siswa dengan persentase sebesar $41 \%$ yang memenuhi KKM IPA 68 setelah diadakan siklus II meningkat menjadi 21 siswa atau 64\%, siswa yang memenuhi KKM IPA 68 dan di siklus III yang mencapai KKM IPA 68 terdapat 27 siswa atau ketuntasan siswa meningkat menjadi $82 \%$ yang artinya telah mencapai ketuntasan belajar yaitu diatas $80 \%$ sehingga tidak perlu diadakan penelitian lagi. Berdasarkan hasil belajar siswa pada pelaksanaan pembelajaran dengan pendekatan keterampilan proses (predict-observe-explain), ditemukan bahwa pada dasarnya pembelajaran ini memiliki potensi yang cukup baik untukr neningkatkan hasil belajar siswa terhadap materi cahaya dan sifat-sifatnya. Hal ini ditunjukan oleh rata-rata hasil tes akhir subjek penelitian yang dilaksanakan pada setiap pembelajaran mengalami peningkatan. Hasil belajar siswa yang baik terhadap konsep cahaya dan sifat-sifatnya mengidentifikasi bahwa pembelajaran dengan pendekatan keterampilan proses (predict-observe-explain) memungkinkan untuk dijadikan sebagai salah satu model pembelajaran dalam meningkatkan hasil belajar siswa dalam IPA khususnya di SD.

\section{KESIMPULAN}

Dengan RPP yang baik, digunakan gurupada pembelajaran yang mempunyai karakteristik berbeda, yaitu dengan menerapkan langkah-langkah pembelajaran Pendekatan Keterampilan Proses, dapat meningkatkan hasil belajar siswa dalam proses pembelajaran hal ini terlihat dari hasil observasi aktivitas siswa dan guru serta catatan peneliti yang hasilnya terdapat peningkatan keterampilan proses di setiap siklusnya dan peningkatan aktivitas siswa dalam pembelajaran. Dari hasil tes belajar siswa mengalami peningkatan, hasil tes siklus I nilai rata-rata siswa adalah 59, pada siklus II nilai rata-rata siswa adalah 68 dan pada siklus III nilai rata-rata siswa adalah 74 .

\section{REFERENSI}

Depdiknas. (2006), Kurikulum Tingkat Satuan Pendidikan (KTSP). Jakarta: Departemen Pendidikan Nasional.

Hedriani. (1995). Petunjuk Guru Alam Sekitar Kita 3, Jakarta: Balai Pustaka.

Indrawati \& Setiawan. (2009). Pembelajaron aktif, kreatif, efehif, dan menyenangkan PAKEM).

Bandung: Pusat Pengembangan danPemberdayaan Pendidik dan Tenaga Kependidikan IImu Pengetahuan Alam (PPPPTK IPA).

Nana Sudjana. (2009). Penilaian Hasil Proses Belajar Mengajar. Bandung: Sinar Baru. 
Pudjiadi. (1996). IImu Gizi pada Anak Edisi Ketiga. Fakultas Kedokteran Universitas Indonesia.

Purba \& Wartono. (1998). Strategi Belajar Mengajar Pendidikan Sains. Bandung: Remaia

Rosdakarya.

Purwanto. ( 2007). Psikologi Pendidikan. Bandung: PT Remaja Rosdakarya. 